\title{
Comparison of Antioxidant and Anti-hyaluronidase Potentials of Pineapple Core Extract (Ananas comosus (L.) Merr.) and Luteolin
}

\author{
Ridza Jusri, ${ }^{1}$ Wahyu Setia Widodo, ${ }^{2}$ Wahyu Widowati, ${ }^{3}$ Delores Elisabeth Sormin, ${ }^{1}$ Adek Irmansyah, ${ }^{1}$ \\ Eddy Fachrial, ${ }^{1}$ I Nyoman Enrich Lister ${ }^{1}$ \\ ${ }^{1}$ Faculty of Medicine, Universits Prima Indonesia, Medan, Indonesia, ${ }^{2}$ Biomolecular and Biomedical Research \\ Center, Aretha Medika Utama, Bandung, Indonesia, ${ }^{3}$ Faculty of Medicine, Maranatha Christian University, \\ Bandung, Indonesia
}

\begin{abstract}
Skin aging processes are divided into chronological aging and premature aging. Premature aging is generally caused by free radicals, from both air pollution and photoaging. Natural compounds from plant extracts are among sources of antioxidants and anti-hyaluronidase which have the ability to prevent antiaging. One of the potential fruits related to antioxidant and antiaging activities is Anana scomosus. A. comosus has a number of phenolic compounds with biological activities. One of the main phenolic compounds in A. comosus is luteolin. The aim of this study was to evaluate the antioxidant and antiaging potentials of pineapple core extract (PCE). This study was conducted at the Biomolecular and Biomedicine Research Center, Aretha Medika Utama from August to November 2018. Analysis of antioxidants from PCE and luteolin was carried out using $\mathrm{H}_{2} \mathrm{O}_{2}$ scavenging activity assay. The antiaging assay was carried out through inhibition of hyaluronidase enzyme, one of the important enzymes in the aging process. Luteolin had lower IC50 value of $\mathrm{H}_{2} \mathrm{O}_{2}$ scavenging activity of around $24.12 \pm 3.13 \mu \mathrm{g} /$ $\mathrm{ml}$, which was better than CPE with IC50 of $304.56 \pm 3.76 \mu \mathrm{g} / \mathrm{mL}$. The results of hyaluronidase inhibition activity assay showed that luteolin compound had a lower IC50 value of $67.38 \pm 3.99 \mu \mathrm{g} / \mathrm{mL}$ when compared to PCE with an IC50 value of $161.15 \pm 1.05 \mu \mathrm{g} / \mathrm{mL}$. Hence, Luteolin has higher antioxidant and anti-hyaluronidase activities than PCE
\end{abstract}

Key words: Antiagin, antioxidants, anti-hyaluronidase, luteolin, pineapple core extract

\section{Perbandingan Aktivitas Antioksidan dan Antihialuronidase Ekstrak Bonggol Buah Nanas (EBN) dengan Senyawa Luteolin}

\begin{abstract}
Abstrak
Terdapat dua jenis proses penuaan kulit, penuaan kronologis dan penuaan dini. Penuaan dini umumnya disebabkan oleh radikal bebas, baik dari polusi udara maupun photoaging. Penggunaan antioksidan dan antihialuronidase untuk mencegah proses penuaan telah banyak diketahui. Ananascomosus merupakan salah satu tanaman yang memiliki potensi sebagai antipenuaan dan antioksidan karena mengandung sejumlah senyawa fenolik yang memiliki berbagai aktivitas biologis. Salah satu senyawa fenolik utama dalam A. comosus adalah luteolin. Tujuan penelitian ini adalah untuk mengevaluasi potensi antioksidan dan anti-aging dari Ekstrak Bonggol Nanas (EBN) dan senyawa pembandingnya yaitu luteolin. Penelitian ini dilakukan di Biomolecular and Biomedicine Research Center, Aretha Medika Utama dari Agustus hingga November 2018. Pengujian antioksidan dari EBN dan luteolin dilakukan menggunakan uji pemerangkapan $\mathrm{H}_{2} \mathrm{O}_{2}$. Uji antipenuaan dilakukan melalui uji penghambatan aktivitas hialuronidase, salah satu enzim penting dalam proses penuaan. Hasil penelitian menunjukkan bahwa Luteolin memiliki nilai $\mathrm{IC}_{50}$ aktivitas pemerangkapan $\mathrm{H}_{2} \mathrm{O}_{2}$ lebih rendah sekitar $24.12 \pm 3.13 \mu \mathrm{g} / \mathrm{mL}$ lebih baik daripada EBN dengan IC ${ }_{50}$ sebesar $304.56 \pm 3.76 \mu \mathrm{g} / \mathrm{mL}$. Hasil uji aktivitas penghambatan hialuronidase, senyawa luteolin memiliki nilai $\mathrm{IC}_{50}$ lebih rendah, yaitu sebesar $67,38 \pm 3,99 \mu \mathrm{g} / \mathrm{mL}$ dibanding dengan EBN nilai $\mathrm{IC}_{50} 161,15 \pm 1,05 \mu \mathrm{g} / \mathrm{mL}$. Hasil ini menunjukkan bahwa senyawa pembanding luteolin memiliki aktivitas antioksidan dan antihialuronidase yang lebih tinggi daripada EBN.
\end{abstract}

Kata kunci: Antihialuronidase, antioksidan, antipenuaan, ekstrak bonggol nanas, luteolin

Corresponding Author: I Nyoman Enrich Lister, Faculty of Medicine, Universitas Prima Indonesia, Medan, Jalan Belanga No.1, Sei Putih Tengah, Medan Petisah, North Sumatra, 20118, Indonesia, Email: yysunpri@gmail.com 


\section{Introduction}

Ultraviolet (UV) irradiation and air pollution exposure cause various diseases in humans today. UV irradiation and air pollution are the main source of exogenous oxidants in the form of free radicals originating from outside the human body. ${ }^{1}$ Ultraviolet exposures and oxidants from the air can accelerate aging. ${ }^{2}$ The age and the continuous exposure of UV light will constantly change the structure of the skin, especially the dermis. This layer contains many collagen, elastin, and proteoglycan fibers, one of which is hyaluronic acid. Hyaluronic acid normally functions as a binding site for collagen and elastin fibers. The increasing of hyaluronidase enzyme due to induction from ultraviolet light and exogenous oxidant will cause signs of aging, such as wrinkles. ${ }^{3}$

Antioxidant is a molecule that has the ability to delay the aging process by maintaining oxidant levels with or without free radical activities. Antioxidants can be given in the form of food supplements for the body or used in skin cares as cosmetic products that act as anti-aging molecules because antioxidants prevent free radicals. ${ }^{4-6}$

It has been known that natural products, such as plant extracts, have good abilities to inhibit aging. ${ }^{7}$ Plant extracts have been known having antioxidant activities and are able to inhibit aging-related enzymes that damage extracellular matrix in the skin tissue. Antioxidant and antiaging activities in plant extracts are caused by natural compounds in the plant extract. The results showed various compounds isolated from plants such as, gallic acid, $\beta$-carotene, catechins, ${ }^{7}$ eugenol, hesperidin, ${ }^{6}$ and myricetin ${ }^{8}$ have good antioxidant and anti-aging activities.

Pineapple fruit is a tropical plant containing various bioactive compounds, such as luteolin, quercetin, myricetin. Luteolin is a bioactive flavone compound. ${ }^{9}$ Luteolin can also be found in various vegetables such as celery, thyme, green peppers, tea and citrus fruits, grapes, and lemons. This compound can act as an antioxidant that has the ability to fight free radicals. ${ }^{10,11}$

Therefore, it is needed to evaluate the potential of antioxidant and anti-hyaluronidase activity of pineapple core extract (PCE) compared to luteolin compounds through antioxidant activity $\left(\mathrm{H}_{2} \mathrm{O}_{2}\right.$ scavenging activity assay) and hyaluronidase inhibitory activity assay.

\section{Methods}

This study was conducted at Biomolecular and Biomedicine Research Center, Aretha Medika Utama from August to November 2018. Pineapple core was obtained from Tambaksari Village, Subang Regency. This study was limited to only in vitro test. The plants were identified at Herbarium Bandungense, Department of Biology, School of Life Science and Technology, Bandung, West Java.

Pineapple core that had been removed from the flesh was dried in a food dehydrator at $70^{\circ} \mathrm{C}$ for 48 hours then the dried simplicial of pineapple core was made into powder. The powder of pineapple core simplicial was then extracted with $70 \%$ distilled ethanol for 24 hours using maceration technique. Ethanol filtrate was filtered and re-macerated in triplicates, and then, the filtrate was evaporated with a vacuum rotary evaporator heater at $70^{\circ} \mathrm{C} .6,12,13$ The yield of Pineapple Core Extract (PCE) was $10.08 \mathrm{~g}$. The luteolin used in this study was purchased from Chengdu Biopurify Phytochemical (Chengdu, PB0896). Antioxidant and anti-hyaluronidase potential of PCE and Luteolin were assessed using in vitro assay. The antioxidant potential was measured using $\mathrm{H}_{2} \mathrm{O}_{2}$ scavenging activity assay and the anti-aging potential of the figure was assessed using anti-hyaluronidase assay.

$\mathrm{H}_{2} \mathrm{O}_{2}$ scavenging activity was measured using the method described by Mukhopadhyay et al. ${ }^{14}$ with modifications. The solution mixture was made as shown in Table 1. After adding $\mathrm{H}_{2} \mathrm{O}_{2}$, a mixture of control, sample, and blank solutions which were inserted into the 96-well plate was incubated for 5 minutes in a dark room at room temperature condition. Thereafter each mixture of sample and blank was added $75 \mu \mathrm{L}$ 1,10-phenanthroline, then incubated again for 10 minutes in a dark room at room temperature condition. The absorption was then measured using spectrophotometer with 510 $\mathrm{nm}$ wavelength. The percentage of scavenging activities was calculated using the equation:

$\%$ scavenging activity $=\mathrm{S} / \mathrm{C} \mathrm{x} 100 \%$, When $\mathrm{S}$ is sample absorbance and $\mathrm{C}$ is control absorbance.

Hyaluronidase Inhibitory Activity Assay was conducted by a method developed by Thring et al. ${ }^{15}$ and Widowati et al. ${ }^{4,8}$. Twenty five (25) $\mu \mathrm{L}$ 
Jusri, et al: Comparison of Antioxidant and Anti-hyaluronidase Potentials of Pineapple Core Extract and Luteolin

Table 1 Solution Composition Used in $\mathrm{H}_{2} \mathrm{O}_{2}$ Radical Scavenging Activity Assay

\begin{tabular}{lccc}
\hline \multicolumn{1}{c}{ Reagents } & Control & Test Sample & Blank \\
\hline Sample & - & $60 \mu \mathrm{L}$ & $60 \mu \mathrm{L}$ \\
Ferrous Ammonium Sulfate $(1 \mathrm{mM})$ & $12 \mu \mathrm{L}$ & $12 \mu \mathrm{L}$ & - \\
DMSO & $63 \mu \mathrm{L}$ & - & $90 \mu \mathrm{L}$ \\
$\mathrm{H}_{2} \mathrm{O}_{2}(5 \mathrm{mM})$ & - & $3 \mu \mathrm{L}$ & - \\
1,10 -phenanthroline $(1 \mathrm{mM})$ & - & $75 \mu \mathrm{L}$ & $75 \mu \mathrm{L}$ \\
\hline
\end{tabular}

of PCE from serial concentration $(166.67 ; 83.33$; 41.67; 20.83; $10.42 ; 5.21 \mu \mathrm{g} / \mathrm{mL}$ ) was mixed with $3 \mu \mathrm{L}$ hyaluronidase enzyme from the bovine testis $(0.4 \mathrm{U} / \mathrm{mL}$ in a $20 \mathrm{mM}$ phosphate buffer, pH 7 in $77 \mathrm{mM}$ sodium chloride and $0.01 \%$ serum albumin bovine), and $12 \mu \mathrm{L}$ phosphate buffer (300 mM, pH 5.35) was incubated for 10 minutes at $37^{\circ} \mathrm{C}$. Afterwards, $10 \mu \mathrm{L}$ hyaluronic acid substrate $(0.03 \%$ in $300 \mathrm{mM}$ phosphate buffer, $\mathrm{pH}$ 5.35) was incubated for 45 minutes at $37^{\circ} \mathrm{C}$. The decomposition reaction of hyaluronic acid was stopped by adding albumin acid $100 \mu \mathrm{L}$ (24 mM sodium acetate, $79 \mathrm{mM}$ acetic acid and $0.1 \%$ BSA.) The mixture solution was incubated at room temperature for 10 minutes, then the absorbance was measured at $600 \mathrm{~nm}$ wavelength using spectrophotometer. The percentage of enzyme inhibition activity was measured by the equation below:

\section{Hyaluronidase Inhibition (\%) = (-C/S) $\times 100 \%$ When $\mathrm{C}$ is control absorbance and $\mathrm{S}$ is sample absorbance. ${ }^{6,8,13,15}$}

The results were analyzed using the SPSS program with One-Way ANOVA test and followed by Post Hoc Tukey HSD test. Furthermore, inhibitory concentration $50 \quad\left(\mathrm{IC}_{50}\right)$ values of antioxidant and anti-aging activity were calculated.

\section{Results}

The $\mathrm{H}_{2} \mathrm{O}_{2}$ scavenging activity assay showed that the luteolin had a better $\mathrm{H}_{2} \mathrm{O}_{2}$ scavenging activity than PCE. The results of $\mathrm{H}_{2} \mathrm{O}_{2}$ scavenging activity were shown in Figure 1. The $\mathrm{H}_{2} \mathrm{O}_{2}$ scavenging activities of PCE and luteolin increased with the increasing of the sample concentrations (concentration dependent manner). Luteolin had a lower $\mathrm{IC}_{50}$ value of $24.12 \pm 3.13 \mu \mathrm{g} / \mathrm{mL}$ than PCE with $\mathrm{IC}_{50}$ value around $304.56 \pm 3.76 \mu \mathrm{g} / \mathrm{mL}$ (Table 2), which means that luteolin had a better antioxydant activity than PCE.

The hyaluronidase inhibitory activity was performed through a spectrophotometric method to measure hyaluronidase activity and to detect the potential hyaluronidase inhibitor. The hyaluronidase inhibitory activity assay showed that luteolin had a better inhibitory activity than PCE (Figure 2). The hyaluronidase inhibitory activities of PCE and luteolin increased with the increasing of the sample concentrations

Table 2 Solution Composition Used in $\mathrm{H}_{2} \mathrm{O}_{2}$ Radical Scavenging Activity Assay

\begin{tabular}{lcccc}
\hline \multicolumn{1}{c}{ Sample } & Linear Regression & R2 & IC50 $(\boldsymbol{\mu g} / \mathbf{m L})$ & IC50 $(\boldsymbol{\mu g} / \mathbf{m L})$ \\
\hline \multirow{3}{*}{ PCE } & $\mathrm{y}=0.1345 \mathrm{x}+9.4135$ & 0.95 & 301.76 & \\
& $\mathrm{y}=0.1323 \mathrm{x}+9.8993$ & 0.94 & 303.10 & $304.56 \pm 3.76$ \\
& $\mathrm{y}=0.1292 \mathrm{x}+10.099$ & 0.93 & 308.83 & \\
Luteolin & $\mathrm{y}=0.132 \mathrm{x}+9.8038$ & 0.94 & 304.52 & \\
& $\mathrm{y}=0.1068 \mathrm{x}+47.053$ & 0.96 & 27.59 & $24.12 \pm 3.13$ \\
& $\mathrm{y}=0.1103 \mathrm{x}+47.627$ & 0.92 & 21.51 & \\
& $\mathrm{y}=0.1094 \mathrm{x}+47.457$ & 0.93 & 23.24 & \\
& $\mathrm{y}=0.1088 \mathrm{x}+47.379$ & 0.94 & 24.09 & \\
\hline
\end{tabular}

*Linear equations, coefficient of regression (R2) and IC50 of each sample were calculated; *PCE = pineapple core extract 
Jusri, et al: Comparison of Antioxidant and Anti-hyaluronidase Potentials of Pineapple Core Extract and Luteolin

Table 3 IC $_{50}$ Values of Hyaluronidase Inhibitory Activities of PCE and Luteolin

\begin{tabular}{lcccc}
\hline \multicolumn{1}{c}{ Sample } & Linear Regression & $\mathbf{R}^{2}$ & IC50 $(\mu \mathrm{g} / \mathbf{m L})$ & IC50 $(\mu \mathrm{g} / \mathbf{m L})$ \\
\hline \multirow{3}{*}{ PCE } & $\mathrm{Y}=0.1345 \mathrm{x}+9.4135$ & 0.99 & 162.72 & \\
& $\mathrm{Y}=0.323 \mathrm{x}+9.8993$ & 0.99 & 160.81 & $161.15 \pm 1.05$ \\
& $\mathrm{Y}=0.1292 \mathrm{x}+10.099$ & 0.93 & 161.01 & \\
Luteolin & $\mathrm{Y}=0.132 \mathrm{x}+9.8038$ & 0.93 & 161.08 & \\
& $\mathrm{Y}=0.1068 \mathrm{x}+47.053$ & 0.96 & 69.21 & $67.38 \pm 3.99$ \\
& $\mathrm{Y}=0.1103 \mathrm{x}+47.627$ & 0.92 & 70.12 & \\
& $\mathrm{Y}=0.1094 \mathrm{x}+47.457$ & 0.93 & 62.80 & \\
& $\mathrm{Y}=0.1088 \mathrm{x}+47.379$ & 0.94 & 67.21 & \\
\hline
\end{tabular}

(concentration dependent manner). The hyaluronidase inhibitory activities of PCE and luteolin based on $\mathrm{IC}_{50}$ value were shown in Table 3 . Table 3 showed that luteolin had a lower $\mathrm{IC}_{50}$ value of $67.38 \pm 3.99 \mu \mathrm{g} / \mathrm{mL}$ than PCE with $\mathrm{IC}_{50}$ value around $161.15 \pm 1.05 \mu \mathrm{g} / \mathrm{mL}$ (Table 3 ). The $\mathrm{IC}_{50}$ value is the concentration of the sample that inhibits $50 \%$ of hyaluronidase activity.

\section{Discussion}

Pineapple (A. comosus) is a tropical plant that has various active compounds. Pineapple contains several active compounds such as quercetin, myricetin, luteolin. ${ }^{9}$ This shows that pineapple contains many active compounds with various biological activities, one of which is luteolin. Luteolin is an important component in pineapple which has a variety of biological activities. ${ }^{10}$

The results of the study regarding the scavenging activities of $\mathrm{H}_{2} \mathrm{O}_{2}$ free radicals by both PCE and luteolin compounds (Table 2 and Figure 1) showed good antioxidant activities. The $\mathrm{IC}_{50}$ value of $\mathrm{H}_{2} \mathrm{O}_{2}$ scavenging activity from Luteolin was $24.12 \pm 3.13 \mu \mathrm{g} / \mathrm{mL}$, smaller than PCE which had IC ${ }_{50}$ value of $304.56 \pm 3.76 \mu \mathrm{g} / \mathrm{mL}$. Widowati et al. ${ }^{8}$ classified antioxidant capacity based on $\mathrm{IC}_{50}$

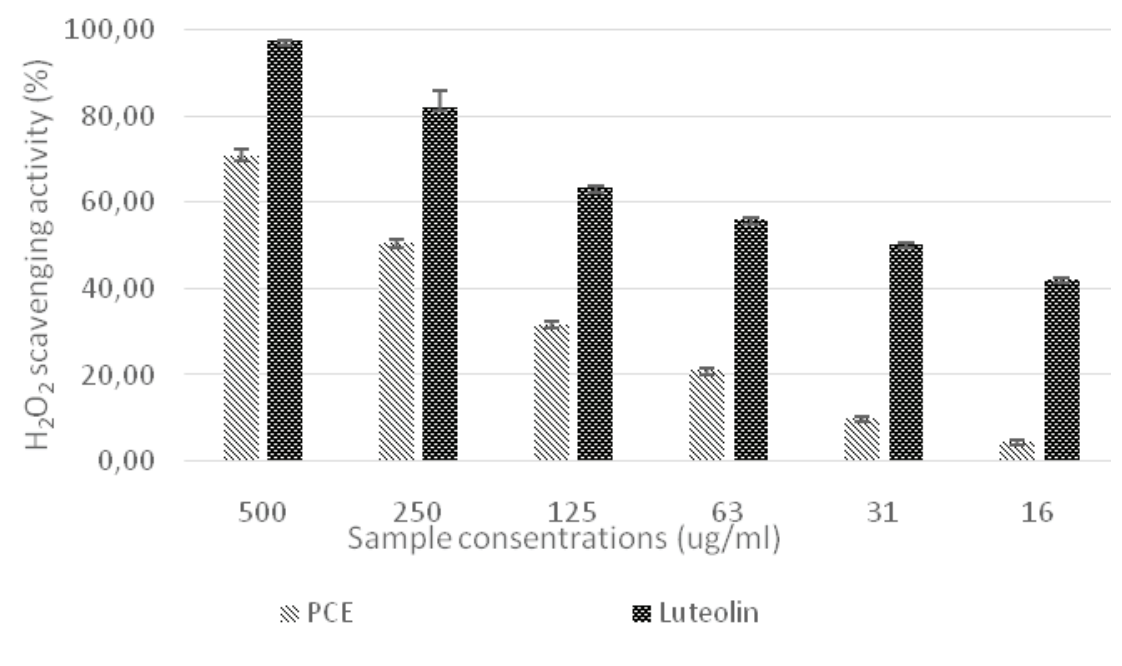

Figure $1 \mathrm{H}_{2} \mathrm{O}_{2}$ Scavenging Activities of PCE and Luteolin

*The data was presented as mean \pm standard deviation. Luteolin and PCE were diluted in DMSO of $10 \%$ to reach the final concentration of $166.67 ; 83.33 ; 41.67 ; 20.83 ; 10.42 ; 5.21(\mu \mathrm{g} / \mathrm{mL})$. The H2O2 scavenging activities of the samples in different concentration were statistically different in $\alpha<0.05$. *PCE $=$ pineapple core extract 


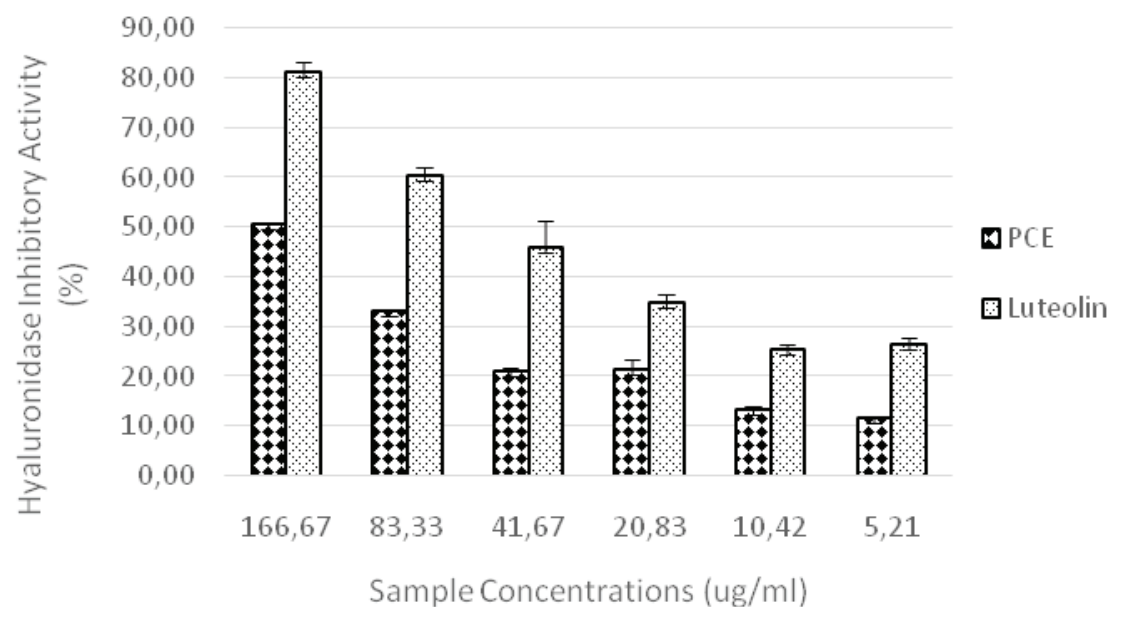

\section{Figure 2 Hyaluronidase Inhibitory Activities of PCE and Luteolin. Luteolin had a higher Hyaluronidase Inhibitory Activity than PCE. The Hyaluronidase Inhibitory Activites of PCE and Luteolin Increased with the Increasing of the Concentration of Sample}

*The data was presented as mean \pm standard deviation. Luteolin and PCE were diluted in DMSO of $10 \%$ to reach the final concentration of $166.67 ; 83.33 ; 41.67 ; 20.83 ; 10.42 ; 5.21(\mu \mathrm{g} / \mathrm{mL})$. The hyaluronidase inhibitory activities of the samples in different concentration were statistically different in $\alpha<0.05 ;{ }^{*} \mathrm{PCE}=$ pineapple core extract

value. A compound has a very strong antioxidant if $\mathrm{IC}_{50}$ is worth $<50 \mathrm{ppm}$, is strong if $\mathrm{IC}_{50}$ is worth 50-100 ppm, while $\mathrm{IC}_{50}$ is worth $100-150 \mathrm{ppm}$, and weak if $\mathrm{IC}_{50}$ is worth $151-200 \mathrm{ppm}$ or more. Based on this classification, it can be concluded that luteolin has a very high antioxidant activity and PCE has a weak antioxidant activity. ${ }^{8}$

This study is in line with other studies that indicated that luteolin is a compound that has a good antioxidant activity. ${ }^{11}$ The results of this study about $\mathrm{H}_{2} \mathrm{O}_{2}$ scavenging activity of PCE indicated that PCE has a very weak antioxidant activity because it has an $\mathrm{IC}_{50}$ value more than 200 $\mu \mathrm{g} / \mathrm{mL}(304.56 \pm 3.76 \mu \mathrm{g} / \mathrm{mL})$. At present, there are no publications regarding the antioxidant activity of PCE. The study from Fidrianny et al. ${ }^{16}$ that conducted antioxidant assay of the peel, flesh and bractea of pineapple fruit showed that the antioxidant activities of the peel, flesh, and bractea are very strong. The $\mathrm{IC}_{50}$ value from fruit flesh and the peel extract from Bogor showed a value below $50 \mathrm{ppm}$. This indicated that PCE is a part of pineapple fruit which has the lowest antioxidant activity. It is expected to compare the antioxidant activities between luteolin and PCE as an active compound which are found in pineapple core. $\mathrm{H}_{2} \mathrm{O}_{2}$ is a radical compound found in many tissues. The higher the $\mathrm{H}_{2} \mathrm{O}_{2}$ trapped by the active compounds, the higher the antioxidant activity has. IC $_{50}$ values are used to represent antioxidant and anti-aging activities on PCE and luteolin. The smaller $\mathrm{IC}_{50}$ values, the better the ability of the active compounds in the activity of trapping free radicals. Table 2 showed that PCE had a lower antioxidant activity than luteolin indicated by the $\mathrm{IC}_{50}$ values. The antioxidant activity of natural compound was determined by the amount of hydroxyl group. The hydroxyl group in the phenolic compound will donate the hydrogen ion to the chain carrying ROD* radicals. ${ }^{6,8}$ The antioxidant ability of a compound is closely related to its anti-aging potential. This is because free radicals found in skin tissue are the main cause of tissue damage. Therefore, compounds having high antioxidant capacity can prevent both chronological and premature aging. ${ }^{17}$ The results of this study indicated that luteolin has a great potential to be developed into compounds for the prevention of premature aging.

The results showed that the PCE inhibitory activity of hyaluronidase and its comparative compounds showed a hyaluronidase inhibition activity with $\mathrm{IC}_{50}$ values of $67.38 \pm 3.99 \mu \mathrm{g} / \mathrm{mL}$ for luteolin and $161.15 \pm 1.05 \mu \mathrm{g} / \mathrm{mL}$ for PCE. The inhibition activity of hyaluronidase from luteolin was classified into a strong inhibitor while the inhibitory activity of luteolin was classified into a weak inhibitory activity. This was also based on the results obtained by Tu \& Tawata, ${ }^{18}$ 
stating that the $\mathrm{IC}_{50}$ value of an extract for antihyaluronidase ranging from $50-100 \mathrm{ppm}$ is considered as a strong inhibitor.

Hyaluronidase is an enzyme that plays a role in the degradation of hyaluronic acid (HA). Hyaluronic acid (HA) is a key compound in the aging process and a glycosaminoglycan polymer that plays a role in tissues. Hyaluronic acid (HA) maintains water levels in the skin, which means it can act as a molecule that can increase skin moisture. Besides its role mentioned above, HA is also an extracellular matrix (ECM) molecule that maintains the elasticity of the skin, ${ }^{19}$ which can be degraded by the hyaluronidase enzyme. In humans, there are 6 types of hyaluronidase enzymes. Hyaluronic acid (HA) degradation occurs through hydrolysis of 1,4-hexosaminidic bonds between $\mathrm{N}$-acetyl-D-glucosamine and D-glucuronic acid which are residues of HA. ${ }^{20}$ Besides being able to be crushed by enzymes, HA can also be degraded non-enzymes by free radicals when there are reducing compounds such as ascorbic acid, thiol, iron ions, and copper ions. Therefore, the use of ingredients that have an antioxidant activity can reduce the degradation of HA in tissues. ${ }^{19}$

In conclusion, PCE has a lower antioxydant and antihyaluronidase than luteolin. Based on the IC50 values, it showed that antioxidant activity and antihialuronisase from PCE are less effective than luteolin. Hence, luteolin has more potential as anti-aging considering antioxidant and anti-hyaluronidase.

\section{References}

1. Plainfossé $H$, Burger P, Azoulay S, Landreau A, Verger-Dubois G, Fernandez X. Development of a natural anti-age ingredient based on quercus pubescens willd. leaves extract-a case study. Cosmetics. 2018;5(1):1-21.

2. Rittié L, Fisher GJ. UV-light-induced signal cascades and skin aging. Ageing Res Rev. 2002;1(4):705-20.

3. Ndlovu G, Fouche G, Tselanyane M, Cordier W, Steenkamp V. In vitro determination of the anti-aging potential of four southern African medicinal plants. BMC Complement Altern Med. 2013;13(1):304.

4. Widowati W, Noverina R, Ayuningtyas W, Kurniawan D, Faried A, Laksmitawati D, et al. Reactive Oxygen Species and Aging Mechanism. Reactive oxygen species (ROS) mechanism and role in health and disease. In: Shannon Wilkerson, editor. Reactive oxygen species (ROS): Mechanism and role in helath and disease. New York: Nova Science Publisher; 2018. p. 101-34.

5. Utami S, Sachrowardi QR, Damayanti NA, Wardhana A, Syarif I, Nafik S, et al. Antioxidants, anticollagenase and antielastase potentials of ethanolic extract of ripe sesoot (Garcinia picrorrhiza Miq.) fruit as antiaging. J Herbmed Pharmacol. 2018;7(2):88-93.

6. Widowati W, B WJ, Nadya S, Amalia A, Arumwardana S, Kusuma HSW, et al. Antioxidant and antiaging activities of Jasminum sambacextract, and its compounds. J Reports Pharm Sci. 2018;7(3):270-85.

7. Mukherjee PK, Maity N, Nema NK, Sarkar BK. Bioactive compounds from natural resources against skin aging. Phytomedicine. 2011;19(1):64-73.

8. Widowati W, Rani AP, Hamzah RA, Arumwardana S, Afifah E, Kusuma HSW, et al. Antioxidant and Antiaging Assays of Hibiscus sabdariffa Extract and Its Compounds. Nat Prod Sci. 2017;23(3):192.

9. Bhagwat S, Haytowitz DB, Holden JM. USDA database for the flavonoid content of selected foods, Release 3.1. Maryland: Department of Agriculture, Agricultural Research Service Beltsville Human Nutrition Research Center Nutrient Data Laboratory; 2014.

10. Kang KA, Piao MJ, Ryu YS, Hyun YJ, Park JE, Shilnikova K, et al. Luteolin induces apoptotic cell death via antioxidant activity in human colon cancer cells. Int J Oncol. 2017;51(4):1169-78.

11. Kasala ER, Bodduluru LN, Barua CC, Gogoi R. Antioxidant and antitumor efficacy of Luteolin, a dietary flavone on benzo(a) pyrene-induced experimental lung carcinogenesis. Biomed Pharmacother. 2016;82:568-77.

12. Utami S, Adityaningsari P, Sosiawan I, Endrini S, Sachrowardi QR, Laksono SP, et al. Antioxidants and anticholinesterase activities of the characterized ethanolic of ripe sesoot (Garcinia picrorrhiza Miq.) fruit extract (GpKar) and xanthone. Trad Med J. 2017;22(3):160-5.

13. Widowati W, Fauziah N, Herdiman H, Afni M, Afifah E, Kusuma HSW, et al. Antioxidant and anti aging assays of oryza sativa extracts, vanillin and coumaric acid. J Nat Remedies. 2016;16(3):88-99.

14. Mukhopadhyay D, Dasgupta P, Sinha Roy D, Palchoudhuri S, Chatterjee I, Ali S, et al. A Sensitive in vitro spectrophotometric 
hydrogen peroxide scavenging assay using 1,10-phenanthroline. Free Radicals Antioxidants. 2016;6(1):124-32.

15. Thring TS, Hili P, Naughton DP. Anticollagenase, anti-elastase and anti-oxidant activities of extracts from 21 plants. BMC Complement Altern Med. 2009;9(1):27.

16. Fidrianny I, Virna V, Insanu M. Antioxidant potential of different parts of bogor pineapple (ananas comosus [l.] merr. var. queen) cultivated in West Java-Indonesia. Asian J Pharm Clin Res. 2018;11(1):129-33.

17. Mandrone M, Lorenzi B, Venditti A, Guarcini L, Bianco A, Sanna C, et al. Antioxidant and anti-collagenase activity of Hypericum hircinum L. Ind Crops Prod. 2015;76:402-8.

18. Tu P, Tawata S. Anti-oxidant, anti-aging, and anti-melanogenic properties of the essential oils from two varieties of alpinia zerumbet. Molecules. 2015;20(9):16723-40.

19. Stern R, Maibach HI. Hyaluronan in skin: aspects of aging and its pharmacologic modulation. Clin Dermatol. 2008;26(2):10622.

20. Papakonstantinou E, Roth M, Karakiulakis G. Hyaluronic acid: A key molecule in skin aging. Dermatoendocrinol. 2012;4(3):2538. 